\title{
POSTMODERN KENTTE KUTSALIN FISYONU VE TÜRK TOPLUMU
}

\section{Muhittin IMIL*}

\begin{abstract}
Öz
Endüstrileşen toplumda en çok zarar görenin kurumsal dini yapılar olduğunu, postmodern zamanların ise bireyin anlam arayışını, söz konusu dini yapıları onarmak yerine sırf dini gruplar, yeni dini hareketler ya da seküler bir dünyanın mütecaviz ve ssrarlı darbeleriyle daha istikrarsız hale getirdiğini söylemek mümkündür. İstikrarsızlık ya da iktidar alanının daralması ihtimali bile kurumsal dinlerin yeni arayışlarla -hiç değilse- normatif duvarlarını ve mevcut müntesiplerini koruma ya da ütopik bir iyimserlikle eski ihtişamlı çağlara dönme konusundaki çabalarını yükselen bir ivmeyle artırmaları için yetmiştir. İslam toplumlarının söz konusu mücadelede varlığını devam ettirebilmeleri için kendilerine özgü ve nesnel değerlendirmelerle sağlıklı bir geleceğe hazırlanmaları elzemdir. Çalışma, küresel etkilerle dönüşmeye devam eden dindarlık algılarının İslam toplumlarındaki geleceği konusunda çıkarımlarda bulunmayı hedeflemektedir. Araştırmanın problemi, kutsal algısının her geçen gün deformasyona uğradığı postmodern çağda Müslümanlık özelinde bireysel dindarlık tezahürlerinin geleceğini sorgulamaktır. Nitel veri toplama yöntemlerinden literatür incelemesi ve meta-sentez yöntemleri kullanılarak gerçekleştirilen araştırmanın amacı, çarpık kentleşme ve iletişim teknolojisindeki gelişmelerle birlikte birey ve toplum üzerindeki postmodern yansımaların, bireysel dindarlık algıları üzerindeki etkilerini açıklamaktır. Bununla
\end{abstract}

* Doç.Dr., Milli Savunma Üniversitesi Misafir Öğretim Üyesi, e-posta: malazgirt2130@gmail.com ORCID : 0000-0001-5124-1984.

Atıf/Cite as: Imıl, Muhittin. "Postmodern Kentte Kutsalın Fisyonu ve Türk Toplumu" Dini Araştırmalar, 24/61 (Aralık 2021), 353-373, https://doi.org/10.15745/da.979203 
birlikte kurumsal dinler ve sırf dini grupların yanında deizm ve ateizm olgularının bireysel dindarlık algılarındaki değişimden nasıl etkilenebileceği sorgulanmıştır.

Anahtar Kelimeler: Postmodernizm, Kentleşme, Kutsal, Deizm, Ateizm, Surf Dini Grup.

\title{
Fission of the Holy in Postmodern Urban and Turkish Society
}

\begin{abstract}
Institutional religious structures are the most damaged in an industrialized society, and in postmodern times, instead of rectifying these harms in religious structures, the individual's quest for meaning is becoming more and more unstable by various religious groups, new religious movements, or the blows of an aggressively and persistently secularist world. Even instability or the possibility of reduction in their field of power has given institutional religions sufficient reason to intensify their efforts to preserve their normative measurements and to protect their existing allies with an attempt to return to their old glorious days, driven by utopian optimism. However, among these movements which are institutional religions with their normative structures, settled organizations, experiences dating back to ancient times and followers reaching up to billions, pure and non-political religious and energetic groups that claim to meet the expectations of millennium or the phenomenon of deism and atheism claiming secular and superficial answers to individual's postmodern search of meaning. The question of which one will be victorious in this field of battle has not been able to be answered yet. Probably, it will be the correct analysis of target group, convenience of methods to reach the receiver and the opponents' relative endurance in this global war in a market, which is liable to the capitalist market conditions to the end to determine the result. It is essential that Islamic societies prepare for a healthy future with their own and objective evaluations in order to survive in this struggle. The study, using literature review and meta-synthesis methods, aims to make inferences about the future of perceptions of religiosity in Islamic societies.
\end{abstract}

Keywords: Postmodernism, Urbanization, Holy, Deism, Atheism, Pure Religious Group.

\section{Summary}

Religion, which declines its majority of social functions such as social constructivism and integration, carried out traditionally in modern society, 
lost the most of its privileged position and has started to be perceived equally with other social institutes. Collective sense of identity of traditional society has started to reduce its meaning and thus normative determinative function of religion in social life and individual awareness has weakened. The world where photos taken all together emphasizing the wholeness and unity in the background has been replaced by selfie craziness and the world is now a world of alone individuals' in-unrestrained crowds away from collectivity and unifying effects. The individual, purifying of atomized traditional identities, -although with less appeal compared to traditional religious structures that have more power of drawing and influencing in zero gravity environmentembarks for new associations which have considerable amount of appeals.

With an ordinary analogy, urbanization based on industrialization has caused holy collectivities to fission, resulting in the creation of unstable nucleuses with different characteristic features in terms of sociology, even if they take their root information from the big whole. These can either be a variety of purely religious groups, cults, congregation structures and new religious movements with different protests against Orthodox religious group or deism and atheism nucleuses standing out their instability.

For an individual who has grown up in traditional patterns of religiousness and perceives the world from the religious point of view, the most suitable harbour in the city is purely religious groups. However, for individuals thinking and living secularly, deism and practical atheism are the most possible natural destinations. An individual -minimizing the sacred space into a vicious circle in the sky through deism, or destroying it by atheism- would experience a loneliness in the middle of a huge universe, a set of uncertainties and problems that can no longer be answered about the world, today and the future, feel a distrustful and an incurable frustration and disappointment right in the place of religious normative structure which $\mathrm{s} / \mathrm{he}$ has deprived himself/herself of the somnolence and borders of. The drug that will treat the individual in this condition is never hidden in the details of his new choice. Thus, deism or atheism lacks the answers to the above-mentioned needs of an urban individual.

In this case, an individual becomes an open target for the missionaries with established institutional structures or purely religious groups offering enthusiasm and ecstasy as well as for various cult communities, new religious movements and Muslimism based on the holy book.

In our view, even though it has some lacks serving to strengthen the problem stated above, religion with a sociological point of view: 
a. If it makes the perception of "other" ambiguous,

b. If it shares its claim/gospel (salvation) with other religious structureswhether or not it is defined as an obvious other-, just as like the Vatican recently called it "interreligious dialog", the Christianization project used as a battering ram for the Islamic world, the religious group, which would later attempt a coup, was in the discourse of "we are one in creed" which is frequently repeated for Christians and Jews,

c. If norms and values defining the identity framework cannot maintain the integrity of the whole, which is backed by vitality and time,

d. If frequency of repetition and loyalty to the rituals (ablution, prayer, fasting, pilgrimage, worship, manifestations of traditional religiosity, etc.) by the followers lessen perceptibly,

e. If it fails to update and prove its discourses to the spirit of time zeitgeist-with a proper language,

f. If it cannot prove theologically that it does not contradict with social change,

g. If it loses its conqueror and messenger character and becomes a dull ideology,

h. If it is not able to construct and manage perceptions of individual religion institutionally,

i. If damage to secular, rationalist or popular sense of religion and discourses of institutional orthodox religion starts to be increased by the religious authority, excluded from mistakes and considered acceptable in every discourse, through his/her sayings and thoughts spreading quickly via mass communication with different reasons (ignorance, politics, secret betrayal etc.),

j. If divisions which occurs with protests, warnings and objections to the Orthodox religious thought exist faster and sharper than acceptable levels and start to damage each other and to the Orthodox discourse,

$\mathrm{k}$. If one or more of these statements take place, it means the danger is near. In this case, if they -the central college of corporate religion, in the words of Craine- cannot implement a set of measures in the perceptions of individual religiosity, it means that they have entered the last step of an evolutionary cycle. A believer of similar religion will not even delay in finding another kiblah to face and altar to pray, in order to satisfy the quest for meaning search that is impossible to end. 


\section{Giriş}

İnsanlık, hızla gelişen iletişim teknolojisinin de etkisiyle uzun zamandır hızlandırılmış ve yoğun bir değişim sürecinin içerisine girmiştir. Bu değişimin en büyük toplumsal yansımalarından birisi de başta dini kimlikler olmak üzere kolektif kimliklerde görülen parçalanma ve çoğalma eğilimidir. Söz konusu eğilimin, zaten geleneksel, modern ve postmodern kesitleriyle belirgin kültürel geçişleri yaşamaya devam eden tranzisyonel toplumları, hatta daha özelde sürekli içerden çatlayarak yeni çatışmaların öznesi olan Müslüman toplumlarl, diğerlerinden daha fazla etkilediğini söylemek mümkündür.

Araştırmanın temel sorunsalı, postmodern çağın Müslüman dindar birey üzerindeki etkilerini irdeleyerek bireysel dindarlık algılarının dönüşümünü sorgulamaktır. Literatür incelemesi ve meta-sentez yöntemleri kullanılarak gerçekleştirilen araştırma, hızlı kentleşme ve iletişim teknolojisinin sosyal yansımalarının; geleneksel, modern ve postmodern görüngülerin aynı anda tezahür ettiği Müslüman toplumların dindarlık algıları üzerindeki etkilerini açıklamayı amaçlamaktadır.

Söylemlerini çağın sorularına cevap verecek biçimde yenileme konusunda yetersiz, öncelik ve özellikle her iki zeminin de arazlarına sahip köy-kentli bir Müslümanlık algısının hızla yaygınlaşı̆̆ı görülmektedir. Böyle bir algının, zamanla artan bir oranla deizm/ateizm düşünceleri ve tamamen sosyolojik/ sosyal psikolojik gerekçelerle sırf dini gruplar, ardından bütün mezhepleriyle yayılmacılık, propaganda ve kapitalist arka plan açısından daha yetkin olan kurumsal Hıristiyanlık lehine kan ve kimlik kaybedeceğini öngörmek kehanet değildir.

\section{Kentleşme ve Dini Değişim}

Son birkaç yüzyıldır endüstriyel gelişimin etkisiyle hızlanan sekülerleşme ve dini çeşitliliğin kurumsal dini yapılara rağmen yükseldiği gerçeği, artık gözlerden saklanamayacak kadar ete kemiğe bürünmüsştür. Günay (2011, 399), sanayileşmiş kentlerde daha fazla öne çıkan özellikleriyle modern toplumun; dinsel yaşantının tezahürleri bakımından çoğulculuk, kurumsal din ve geleneksel dindarlık algılarında çözülme, hatta her ikisine karşı genişleyen bir inançsızlık düşüncesiyle öne çıktığını belirtir.

Sosyo-kültürel ve ekonomik açıdan merkezin önemli oranda uzağında konumlanan çevrenin dini hayatı;

a. İçerdiği nazar, büyü, kurşun döktürme, yatır ve türbe ziyareti gibi din dışı görüngülerle belirginleşen popüler halk dindarlı̆̆ı, 
b. Geleneğin modern değerlerle temasında, dinin ideolojik olarak alg1lanmasını ifade eden, sosyal ve siyasal etkileşime oldukça hassas hale gelmiş dini yönelimler ve gruplar,

c. Modern yaşantıyı ve değerleri kısır bir çatışma ya da dışlama ekseninden çok, idrak edilen hayatla uyumlu hale getirme çabasındaki, uzlaşmacı, birey odaklı dini eğilimleri ile bunların tamamı ya da bazılarının birlikte olduğu bir çeşitlilik içerir (Çelik, 2013, 125).

Kurumsal din, daha önce başarılı olduğu ontolojik güvenliği sağlama konusunda toplumsal değişimle birlikte bazı eksiklikler yaşamaktadır. Söz konusu eksiklikler, geleneksel dini söylemin sosyal değişimle birlikte ortaya çıkan sorunlara çözüm getirme yeteneğinin giderek azalmasıyla birleşince birey, alternatif çözüm yolları arayışına sürüklenmiştir. Geleneksel dini yapının biçimlendirdiği zihinsel ve kurumsal değerler, değişimin getirdiği eşitsiz, yoksun ve güvensiz koşullar tarafından modernitenin vuruşları karşısında tartışılmaya başlanmış ve değişime zorlanmıştır. Modern dünyanın söz konusu seküler karakteri, kurumsal dini yapıların birlik (tevhit) söylemine rağmen geliştiğinden, dinsel birliğin dağılışı, seküler tavrın dayatması ve aynı zamanda kaçınılmaz sonucudur. Zira kurumsal dini yapılar, birlik şiarıyla parçaları birleştirmeye dönük bir hedefe sahipken seküler tavrın aksi istikamette bir etkisi ve işlevi söz konusudur (Akgül, 2012, 196-198).

Tekdüze bir yaşantı, kültürel farklılıkların ortadan kalkarak kitle haline gelme, tek tip eğitim, bilginin kitleselleşmesi ve boş zaman etkinliklerinin pasif hale gelmesi, kent yaşantısının potansiyel mekanik bir eğilime sahip olduğunu gösteren olgulardır (Laborit, 1990). Bu olgularla birlikte kentin kurumsal yapısının parçalanarak bireylerden bağımsız gelişimi, tek tek fertlerin toplumdan yabancılaşarak kopuşunu, bireysel dünyalarla kurumsal çevreleri arasındaki mesafenin artışını tetikleyecektir (Zijderveld, 1985). Geleneksel değerler bütününün kuşatıcılığını devreden çıkararak söz konusu olgularla biçimlenen bürokratik düzen, toplumsal ilişkileri, kentin kurumsal yapıları ve kurallar manzumesiyle sarmalar. Kentin birey üzerindeki olumsuz etkileri, büyük kalabalıklar içinde yalnızlaşan bireylerin, kadim geleneksel aidiyetlerinin özlemiyle cemaatlere yönelmelerine ya da kentin ruhsuzluğuna inat farklılıklarını ispat etmeye çalışmalarına neden olacaktır (Sarıbay, 1996, 40-41).

Modern kent yaşantısında etkinliğini kaybeden dinlerin boşalttığı zemini, yeni ve uygun yapıların dolduramaması, başka sorunlara yol açabilecek niteliktedir. Dinin temel fonksiyonları olan anlam kazandırma, bütünleştirme ve özdeşlik sağlama gibi ihtiyaçların, modern gerçeklik tasarımlarıyla hangi 
düzeyde karşılanabileceği tartışmalıdır (Çelik, 2013, 32). Zira modern toplumda geleneksel olarak icra ettiği toplumsal inşa ve bütünleşme gibi sosyal işlevlerin önemli bir kısmı örselenerek zayıflayan din, ayrıcalıklı tahtını terk etmek zorunda kalarak diğer sosyal kurumlarla eşit seviyede algılanmaya başlamıştır. Geleneksel toplumun sahip olduğu kolektif aidiyetler anlam kaybına uğramış, dinin toplumsal hayatta ve bireysel bilinçte sahip olduğu normatif belirleyiciliği zayıflamıştır. Topluca çektirilen ve arka planda bütüne vurgu yapan fotoğrafların yerini özçekim (selfie) akımının aldığı dünya, artık kolektif bütünlük ve etkilerden uzak, kontrolsüz kalabalıklar içindeki yalnızların dünyasıdır. Atomize olarak güç kaybeden geleneksel aidiyetlerden kurtulan birey, yerçekimsiz ortamda çekim ve etkileme gücü geleneksel dini yapılara oranla daha düşük olsa da cazibesi hiç de küçümsenemeyecek yeni birlikteliklere açık hale gelmiştir.

Kentin kadim kolektif aidiyet ve denetim kalıplarından uzaklaştıran yapısı, geleneksel ve ana akım dini anlayışın dişında farklı ve kentli duruşlarıyla yeni dini yorumların zemin bulmasını sağlar. Kentin söz konusu iklimi dinsel açıdan özgürleştirici bir tesir gücüne sahiptir. Kent, kendisine atfedilen bu özelliklerle Batılı sosyolojide, bireysel, seküler kültürü ortaya çıkaracağı varsayılan bir değişim etkeni sayılmıştır (Çelik, 2013, 141).

Din, hızlı kentleşme ve sanayileşme süreçlerinde oluşan kişilik ve kimlik problemlerini, insanların güven ve dayanışma gereksinimlerini, aidiyet ve anlam arayışlarını tatmin edecek himaye ve ağ sistemi işlevleriyle sahneye yeniden çıkar (Çelik, 2013, 141). Dünyevileşmenin bir sonucu olarak dini gruplar, bir kısmı örgütlü bir kısmı ise daha yaygın bir kurumsallığa sahip çeşitli din dışı rakiplerle dünya tanımlama konusunda mücadeleye zorlanır. Sonuç olarak önceleri yetkeyle dayatılan din artık pazarlanmak durumundadır. Çoğulcu konum her şeyden önce bir pazar konumudur. Dini gruplar örgütlenmelerini, aynı amacı taşıyan rakiplerinin önüne geçerek tüketicilerini arttıracak şekilde yapmak zorundadırlar. Dini kurumlar içinde bürokratik yapıların yaygınlaşması, farklı teolojik geleneklerin ne olursa olsun giderek artan bir oranda sosyolojik olarak birbirlerine benzeşmeleri sonucunu doğurur (Berger, 2005).

Fizikte bir atom çekirdeğinin bölünmesi olayı, Türkçede "bölünme, parçalanma veya parçalara ayrılma" şeklinde karşıllı̆ını bulan "fisyon" kelimesiyle nitelendirilir. Kütle numarası çok büyük bir atom çekirdeğinin parçalanarak kütle numarası küçük iki çekirdeğe dönüşmesini ifade eden fisyon reaksiyonları sonucunda, "kararsı çekirdekler" ve "nötron" oluşur. Çok sıradan bir analojiyle endüstrileşmeye dayalı kentleşme, kutsal bütünlükleri fisyona 
uğratmış, bu parçalanma neticesinde kök bilgilerini büyük bütünden alsalar da farklı karakteristik özellikleriyle sosyolojik açıdan kararsız çekirdekler oluşmuştur. Bunlar Ortodoks dini gruba yönelttikleri irili ufaklı protestolarla tarikat/cemaat yapılanmaları ve yeni dini hareketler benzeri çeşitli sırf dini gruplar olabildiği gibi kimi zamanda kararsızlıklarıyla daha ön plana çıkmış olan deistik ve ateistik çekirdeklerdir.

\section{Fisyon Parçacıkları: Deizm, Ateizm ve Sırf Dini Gruplar}

Deizm, -ateizmin tersine- Tanrının varlığını kabul etmekle birlikte ana akım dini anlayışı tanımlayan teizmden büyük oranda farklı "akılcı Tanrı" anlayış1nı betimler. Deizmin ortaya çıkışında ampirik bilimlerin yükselişi, astronomi ve coğrafya alanındaki keşiflerin yarattı̆̆ 1 yeni bir bakış açısı, Descartes'ın felsefi kuşkusu ve rasyonel yöntemi, Bacon ve izleyicilerinin ampirisizmi ve 17 'nci yüzyıl politik değişimleri etkili olmuştur. Tanrının evreni yarattıktan sonra müdahale etmediğini savunan deizm, dinin kurumsal boyutuna, Hristiyanlıktaki üçleme öğretisine, tek Tanrılı dinlerin aracı peygamberlerine, ruhban sınıfına ve tüm din adamlarına kapılarını kapatır. Deizme göre dini farklılıklar, insanın masum hataları ya da kötü niyetli tavırlarından kaynaklanır. Masum hatalar, bilgisizlik, korku ve hatalı akıl yürütmeden kaynaklanırken, din adamları, rahipler ya da kötü yöneticiler, insanları kontrol etmek ve zayıflıklarından faydalanmak için sonradan güç ve baskıyla devam ettirdikleri kötü niyetli tavırlar sergilerler. Ateizm ise mutlak bir yaratıcı yahut yaratıcıların olmadığı inancını savunan felsefi akımdır. Teist Tanrı inancına tepkisel olarak ortaya çıkan ateizm, pratik ve teorik olmak üzere ikili bir tasnife tabi tutulur. Teorik ateizm, yaratıcının varlığını, tamamen reddeden bir düşünce sisteminin ifadesidir. Pratik ateizm ise bireysel yaşantının aşkın bir dünya dikkate alınmadan sürdürülmesi ve genel yaşamda sadece dünyevi değerlerin geçerli olması anlamına gelir. (Cevizci, 2010, 153-154, 406-407). Endüstri toplumu, öncelikle deney ve gözleme dayalı bilginin kutsanması sonucunu doğurmuş, bu durum bireysel dindarlık algılarını giderek daraltmak suretiyle kutsal evrenin dünyevi belirleyiciliğini törpülemiştir. Bilimsel bilginin yayılışı ister istemez daha fazla sorgulanan dini düşünce ve bilginin, cari hayata ilişkin alanların tümünden çekilmesine ve pratik ateizmin yayılmasına vesile olmuştur.

Din sosyolojisinin genel kabul gören ikili tasnifine göre akrabalık, kan bağ 1 gibi çeşitli bağların yanı sıra dini bağları da olan aile, aşiret, kabile, klan, köy gibi gruplar, doğal dini gruplar, sadece dini bağla birbirine bağlanmış olan gruplar ise sırf dini gruplar olarak adlandırılmaktadır. Çağımızın kolektif 
yükümlülüklerinden kurtulurken kolektif koruma kalkanlarından da mahrum kalan birey, anlam içeriğgine kısaca değinilen deizm, ateizm ve çeşitli sırf dini grupların kolayca nüfuz edebileceği bir yapıya evrilmiştir.

\section{Kentleşme ve Kutsal Dünyanın Patolojileri}

Kutsal evren, eski ihtişamlı konumunu modern zamanlarda hızla terk etmek durumunda kalmıştır. Söz konusu güç kaybı, bireysel ve sosyal hayatta profan alanın artmasına, zahiri dindarlıkta zıt yönde farklılaşmalara, büyük dini grup$\tan$ itiraz ve protestolarla bölünmelere, sıklıkla düşünce ve taraf değiştiren ya da fundamentalizme savrulan müntesiplere, en nihayetinde deizm ve ateizm olgularının sıradan bireysel tercihler olarak daha belirgin hale gelmelerine vesile olur. Bireysel zihin dünyasını ve toplumsal hayatı eskiden olduğu kadar sarmalayamayan hâkim dini yapı, çeşitli alt fırkaları, deizm/ateizm ve hatta coğrafyada esamisi okunmadığı halde cılız varlık mücadeleleri sergileyen diğer dinler ile eşit bir seçenektir artık. Tercih edilmesinin en az edilmemesi kadar mümkün olduğu bir seçenek. Tercih edilme oranını artırması, modern kent pazarında alıcısına ulaşmak için uyguladığı pazarlama yöntemlerine doğrudan bağlı olan sıradan bir seçenek.

Kentlerin kısa zaman dilimlerinde birden büyüdüğü küresel yarışı gerilerden takip eden ülkeler, genellikle kentin ön şartı olan zihinsel altyapıyı oluşturma konusunda gecikmeler ve buna bağl1 eksiklikler yaşarlar. Gelişmiş ülkelerde kentleşme olgusu, sanayileşmenin bir getirisi olarak sonradan gelişirken gelişmekte olan ülkeler, sanayileşemeden hızla büyüyerek kalabalıklaşan kentlere sahiptir (Çelik, 2013, 28). Dini-kutsal alanın kent hayatında her halükarda daraldığını söylemek mümkün ise de bunun tüm dünyada benzer tezahürlere sahip olduğunu iddia etmek doğru olmayacaktır. Sanayileşme olgusuyla birlikte doğal süreçlerinde büyüyen Avrupa kentleri, sekülerleşmeyi kutsal dünyanın hem birey hem de toplum hayatında daralarak zamanla minimize olması şeklinde idrak etmektedir. Batılı sekülerleşme; modernite, rasyonalizasyon ve çeşitli başka faktörlerin etkisi ve yekdiğerini döngüsel biçimde tetiklemesi sayesinde üçüncü dünyadan daha farklı seyretmektedir. Üçüncü dünyanın, sanayileşmenin yetişemediği devasa köyler biçiminde $b a$ lonlayan kentleri, bünyelerinde çok kuvvetli mekanik bağları taşımaya devam ettiklerinden dini alan, Avrupa'daki benzerleri gibi minimize olmak yerine "tahrif" olmaya daha mütemayildir. Bu haliyle form değiştiren Ortodoks dini anlayışın, genellikle şehirde daha kolay tutunum noktaları bulabilecek birçok mitoz bölünmeye uğraması mümkündür. Aslının temel özelliklerini zahiren 
taşımakla birlikte, eylem-söylem çizgisinde mevcut normatif yapıya ters bir tutum geliştiren söz konusu yansımalar, donuk, resmi, gri ve anonim şehir hayatından bir kaçış noktası olarak önemli işlevler görür, aynı zamanda sosyal bir ihtiyaca da karşılık gelirler.

Çelik (2013, 34), kırsal yapıların şekilci, ritüalist, büyüsel, mistik halk dindarlığı, kentin ise akılcı, bireyselleşmiş, özel yaşamın belirli anlarına çekilmiş bir dindarlık ile ön plana çıkmakla birlikte çarpık kentleşmenin farklı tezahürleri de ortaya çıkardığını belirtir. Ayrıca Ona göre, geleneğin kentteki temsili daha çok küçük esnaf yapıları bünyesinde, muhafazakâr esnaf dindarlığı ile kaynaşmış biçimde öne çıkarken, kentli dindarlık biçimleri daha çok ekonomik ve kültürel seçkinler arasında yer bulur.

Kent, bireysel yaşantı ve düşüncenin arttı̆̆ 1 bununla birlikte yabancılaşmanın ortaya çıktığı bir yaşam sahasıdır. Aile ve akrabalık gibi geleneksel dayanışma ve aidiyet bağlarının çözülmesi, devasa kurumların ve bürokrasinin mekanik düzeni, aşırı uzmanlaşmanın ve rasyonalizasyonun getirdiği psikolojik gerilimler, kuşaklar arası iletişimin zayıflaması, aylaklık, suç ve güvensizliğin çoğalması gibi sorunlar nedeniyle kent, adeta şahsiyet, benlik ve kimlik krizlerinin de habercisidir. Kent ortamı, kırsal geleneksel çevrede görülmeyen pek çok kişilik ve kimlik problemlerinin ortaya çıktığı bir yerdir. Bireyler, kentin yalnızlaştırıcı ve yabancılaştırıcı atmosferinde çoğunlukla yerel, kültürel, politik ya da dini gruplara dâhil olarak huzur ve güven eksiklerini tamamlamak isterler. Elbette cemaatlerin kentte var olmasının nedeni sadece ekonomik ve sosyal sorunlara indirgenemez. Dine yönelişin maddi olmayan sebepleri arasında varoluşsal krizler, hayatı ve dünyayı anlamlandırmada mevcut düşünce sistemlerinin yetersizlik göstermesi, modernitenin çevre, insan hakları, toplumsal adalet gibi yeni sosyokültürel ve ekonomik krizlerle baş edememesi de yer almaktadır (Çelik, 2013, 140).

Kentli yaşamın özgürleştiren bireyselci yönü, genellikle yüksek seviyede bir yalnızlaşmaya yol açar. Kolektif aidiyetlerden koparak özgürleşen bireyler, bu sefer de devasa kurumlar karşısında kendilerini daha zayıf ve yalnız hisseder. Bu durum, bazen bireylerin kentli sosyal dayanışma formlarına yönelmesine, bazen de bireyselliği engelleyen cemaat yapılarında sıkışıp kalmasina vesile olabilir (Ayata, 1994, 326). Sosyal ilişkilerde görülen resmi, soğuk ve anonim tavır, kişilerin koruyucu, samimi ve kuşatıcı bağlarla öne çıkan cemaat yapılarına yönelmeleri için uygun zemini oluşturur (Sarıbay, 1996, 41).

Rasyonel, bürokratik organizasyonları kullanma gerekliliği, şehir insanında zamanla değerlerin nitelikselden niceliksele evrilmesine, hesapçı, rasyonel ve 
ölçülü davranış kodlarının ortaya çıkmasına sebep olur (Simmel, 2009, 319). Kısa zamanda şehrin hengâmesine ayak uydurup kalabalıklara karışan bireyin kutsal alana bakış açısı da profan alanda olduğu gibi nicel, hesapçı, bireysel ve rasyonel bir dönüşüm geçirir. Artık din, kırdan getirdiği toplumcu, kolektif, hayırsever formu ve anlam içeriğini kaybetmiştir. Bunun yerine nominal bir evrene dönüşmüş, günah-sevap, hayır-şer, cennet-cehennem tasavvurları sayısal ifadelerle mazrufun kaybolduğu zarflara, ulaşılabilir/anlaşılabilir metadatalar bütününe dönüştürülmüştür. Dini dünyanın bütün uhrevi içeriği ete kemiğe büründürülüp daha kolay ulaşılabilir hale getirildiğinden, geleneksel ve modern arası bir yerlerde arayış içindeki birey, dini slactivizm ya da dini clicktivizm olarak isimlendirilebilecek ve basitçe dijital eylemcilik olarak ifade edilebilen patolojik tutumlara gark olur. Avucunda tuttuğu elektronik dünyada sadece bazı tuşlara dokunarak rahatlatıcı bir eylemsellik içinde olduğuna inanır. $\mathrm{Bu}$ dünyada sosyal mecralardan alınan bir elektronik mesajın kimseye göndermeden silinmesi, günah, cehennem azabı, rızkın azalması, sıkıntı ve belalara maruz kalınacağına işaret eder. Ne kadar fazla paylaşılırsa o kadar çok sevap kazanılacağı düşünülür. Sohbet grupları üzerinden salavat zincirleri kurulur, herkes kendisine verilen vazifeyi yerine getirerek Hz. Peygamberin şefaatine nail olmanın doyumsuz hazzını yaşarken aynı zamanda sanal bir aidiyetle ruhunu doyurur.

Çelik $(2013,15)$, bu durumu gelişen rant kültürüyle açıklar. Ona göre Anadolu kentleri, sosyoekonomik gelişmelere paralel sosyopolitik gelişme ve demokratikleşme ile muhafazakâr dindarlaşmadan nasibini almakta, otokratik yapının gevşemesi ve demokratik kültürün gelişimi, dinin geleneksel algısından seküler ve modern yorumuna doğru geçişi de hızlandırmaktadır. Dindarlık geleneksel kalıplardan ziyade kentsel kalıplara göre şekillenirken, kentler bu hızlı gelişimde kolay yoldan köşe dönme, adam kayırma, yolunu bulma, grubunu öne çıkarma gibi siyasal kültürün rantiyesini yaygınlaştırmaktadır. Kentler, bu rant kültürünün ekseninde burjuva dindarlığı, gösterişçi dindarlık gibi yeni kalıplarla çeşitlenirken gelenekselden arabeske, arabeskten ranta ve yeni mikro dindarlıklara doğru gelişen bu dönüşümün hızını ve diğer etkilerini kestirmek mümkün değildir.

Geleneksel dindarlık kalıpları içerisinde yetişmiş ve dünyayı din penceresinden okuyan bireyin kolektif dini arayışları için kentte sığınabileceği en uygun limanlar, ekseriyetle sırf dini gruplardır. Ancak daha seküler yaşayan ve düşünen bireyler için deizm ve pratik ateizm ulaşılması en mümkün doğal varış noktalarıdır. Kutsal alanı deizmle gökyüzünde fasit bir dairenin içerisine 
sıkıştıran ya da ateizmle yok eden bireyin yaşaması muhtemel sıra dışı bir dizi gelişme söz konusudur. Bu durumdaki birey, sınırları ve ağırlığından kurtulduğu dini normatif yapının yerinde koca bir evrenin ortasındaki yalnızlık, dün, bugün ve gelecekle ilgili artık cevaplanamayan bir dizi belirsizlik, oldukça yoğun yaşamak zorunda kalacağı bir güvensizlik hissi ve devası olmayan düş kırıklıklarını bulacaktır. Bu durumdaki bireyi tedavi edecek ilaç, asla yeni tercihinin ayrıntılarında gizli değildir. Dolayısıyla deizm ya da ateizm, kentli bireyin yukarıda sıralanan ihtiyaçlarına verilmesi muhtemel cevaplardan yoksundur.

Kent dindarlığının sıradan bir tezahürü olan deizm ve ateizm, gerek ontolojik gerekse epistemolojik manada bireyin mensubu olduğu din dairesinin o zamana kadar sağladığ 1 toplum kurma, kolektif bilinç ve güven duygusunu vermekten uzaktır. Kentli birey, deist ya da ateist olsa da bunu biz duygusu ve güçlü kolektiviteyi kaybetme pahasına yapar. Bunun milenyumdaki tek istisnası sivil toplum hareketleri ya da sanal dünyadır. Oysa her ikisi de kaybedilenleri kısmen bile olsa karşılamaktan son derece uzaktır.

Postmodern kentli bireysellik; sanal dünyanın bireyi sosyal kontrol mekanizmalarından kurtarmak suretiyle sağladığı ahlaki özgürlük, din adına fikir serdedenlerin bireysel dindarlıktan uzaklaştıran söylemleri ve sırf dini grupların liderden müntesiplere kadar siyaset ve ticaretlerine yol açmak, yapıp ettiklerini meşrulaştırmak için araçsallaştırdıkları din olgusuyla birleşince, birey deizm veya ateizm düşüncesine daha yakın bir noktada bulur kendisini. Ancak kent organik dayanışmayı dayatan yapısıyla yalnızların mekânı değildir. Geleneksel formlardaki dayanışma biçimlerinden uzak kalan birey, kentin kalın duvarları arasında kaybolmamak ya da ezilmemek için bir kolektif dayanışmaya ihtiyaç duyar. Kırsalda herkesin malumu olduğu temel doğa yasası, aktörleri değişmekle birlikte güvenlikten yoksun kent sokaklarında da geçerlidir: Sürüden ayrılanı kurt kapar. Deizm ve ateizmin bireysel alanı, ona bu kolektif huzuru sağlayamaz. Bu durumda birey, çeşitli kült topluluklar, yeni dini hareketler, resmi dini söylemin dışında cezbeyi ve coşkuyu da sunan sırf dini gruplar ya da kökleşmiş kurumsal yapılarıyla misyoner örgütler için açık hedef haline gelir.

Deist/ateist dünyayı tercih eden birey için bu dünyalar, kararlı, sabit, ruhsal doyum sağlayan yerleşkeler olmaktan ziyade, bir sonraki istasyona hareket edene kadar kısa süreli oyalanacağı duraklar ve belirlenmiş zamanın sonunda terk edeceği mola yerleridir. Yüzeysel bir inşaya sahip oldukları için geçiş ya da soluklanma amaçlı kullanım için yeterli, ancak kalıcı bir manevi yerleşke- 
nin sahip olması gereken asgari şartlardan yoksundurlar. O halde temel soru, bireyin inanç dünyasındaki yolculuğunu noktalamaya karar verdiği son istasyonun içeriği olmalıdır. Kanımızca bu durumdaki bireyi bekleyen iki seçenek mevcuttur.

Bunlardan ilki modern kentte içinde filizlendiği ana gövdeyle aynı seviyede birer seçenek olma hakkını ele geçirmiş olan sırf dini gruplardır. Bunların bir taraftan ayrıldıkları ana gövdenin yerleşik kurumsallı̆̆ını kullanma, diğer yandan kentli dindarlık ihtiyaçlarına verebilecek cevaplarla birlikte coşkuyu sunma gibi avantajları da mevcuttur. Toplumun kıyısında kalmışlardan amaçlarını tüketmiş zenginlere, doğru istikameti arayan kaybolmuşlara kadar toplumsal yelpazenin her noktasına talip olan sırf dini gruplar, coşkulu kolektiviteleri ile deist/ateist birey için de bir dönüş ve nedamet noktası olma potansiyelini taşırlar. Modern kent dindarlığı ihtiyaçlarından kaynaklanan özgün yapıları gereği, diyanetin dışında ticaret ve siyasetin de aktif oyuncuları olduklarından dini, ticari ve siyasi mesajları/tavır alışları birbirine karışırken aslında dünyevileşme/sekülerleşme sürecini hızlandırmaya yardımcı olurlar. Aranan şey, kolektif bir dünya, büyük bir bütünün verdiği güvenlik duygusu, sarmalanmış bir hayat, ticaret ve siyasette kendiliğinden açılan kapılar ve güçlü bir sosyal kimlik ise daha iyisini bulmak oldukça zordur. Üstelik 21 'inci yüzyılda rasyonel yapılar haline gelmiş olan söz konusu gruplar, hem dini hem de dünyevi bohçalar taahhüt ettikleri bireye ulaşmak için mevcut tüm yolları kullanmak suretiyle sürdürülen nihayetsiz bir müntesip avının yorulmak bilmez takipçileridir.

Bu durumdaki ikinci seçeneğin, -resmi ruhsatlı av belgeleri eşliğinde- kurumsallaşmış müntesip avcıllğı ile misyoner örgütlenmeler ve sonunda hangisi önce ve doğru araçlarla ulaşmış ise Katolik, Protestan ya da Ortodoks Hıristiyanlık olduğu değerlendirmekteyiz. Tıpkı sürüden ayrılan kuzu metaforunda olduğu gibi en uygun ve kolay av olarak arafta kalmış bireye yaklaşım metotları, tüm yırtıkları yamayacak, tüm eksikleri tamamlayacak, tüm beklentileri karşılayacak ve tüm sorulara cevap verecek müşfik söylemlere sahiptir.

Arayıştaki bireyin olası uğrak noktaları olarak telaffuz edilen deizm ve ateizm olgularının Batı'daki sebep ve sonuçlarıyla İslam dünyasındaki sebep ve sonuçları arasında da bize göre önemli farklılıklar vardır. Her iki olgunun Batı dünyasındaki gelişimi, modern dünyanın seküler değerleri, endüstri toplumu, bireyin kendine, topluma, dünyaya ve kültüre yabancılaşması gibi kavramlarla açıklanır. Hatta Weberyen bir bakış açısıyla süreci tetikleyen asıl çıkış noktası yine Hıristiyan dünyanın kendi içerisinden kaynaklanmaktadır. Avrupa'da ki- 
lisenin içinden ve kiliseye karşı başlayan reddiye, Protestan ahlakın öğretileri sayesinde endüstriyel üretimi ve sonuçları itibariyle küreselleşmeyi tetiklemiştir. Bugün küreselleşme kavramına daha yukarıdan bakıldığında Protestan cemaatlerin söz konusu süreçte etki üretiminin tam da merkezinde olduğu rahatlıkla görülecektir. Batı, yine dini figürlerin tetiklemesiyle seküler bir dünya görüşüne doğru evrilmiş, deizm ve ateizm olguları ise bu bağlamda daha göze görünür bir hale gelmeye başlamışlardır.

Oysa İslam dünyasında bahse konu olguların yayılım gerekçesi, daha çok küreselleşmenin temel argümanları olan kitle iletişimi, sermayenin sınır tanımayan dolaşımı ve küresel bağımlılık kavramlarıyla açıklanmalıdır. Müslüman toplumlar, Batı dünyasının gerekçelerinden uzak bir şekilde, özellikle kitle iletişiminin sağladığg sınırsız özgürlükler zemininde dini açıdan çözülme tehlikesini yaşamaya devam etmekte, yaşanan şekliyle İslam ya da Halk İslam'1, toplumsal bütünlüğü sağlama işlevinden her geçen gün biraz daha kan kaybetmektedir. Bu bağlamda Batılı deizm/ateizm, geri döndürülmesi çok daha güç olgunlaşmış bir seküler düşünceyle açıklanabilirken, Müslüman toplumlarda endüstriyel ve bilimsel üretim kavramlarıyla bağlantısız olarak mevcut dini algıların kırılması şeklinde gerçekleşmektedir. Bu durum Müslüman toplumlarının her geçen gün ayrıksı biçimde daha fazla tanık olmaya başladıkları deist/ateist kitlenin diğer dini grup telkinlerine daha açık hale geldiğinin göstergesidir.

Postmodern dünyanın imkânlarını en iyi şekilde kullanarak kendi propagandasını gerek nicelik gerekse nitelik açısından en tatminkâr biçimde gerçekleştiren kurumsal dini yapı, tartışmasız biçimde çeşitli mezhepleriyle Hıristiyanlıktır. Geleneksel medyadan sosyal medyaya, internet üzerindeki tüm mecralardan klasik misyonerlik faaliyetlerine kadar kurumsallaşmış H1ristiyan propagandası için temel ya da en kolay hedef kitle, yukarıda sıralanan gerekçelerden ötürü kesinlikle diğer Hıristiyan mezhepleri ya da kendi toplumları içindeki mantıksal çerçevelerini oluşturmuş deist/ateist kesimler değildir. Halk İslamı'nın örselenen sosyal işlevlerine koşut olarak Müslüman toplumların bu devirde yaşadıkları sosyal bunalım, kendi içindeki kent dindarlığının patolojisi olarak öne çıkan deist/ateist azınlık başta olmak üzere arafta kalmış, savrulan kitleleri Hıristiyan propagandasının açık hedefi haline getirmiştir. Çünkü İslam toplumunun içerisinde vücut bulan deizm/ateizm, Batılı benzerlerine kıyasla daha kararsız, tepkisel, sağlam bir zemine oturmamış, zihni olgunluğa erişmemiş, tartışılmamış, düşünülmemiş olmakla birlikte tepkisel bir tutum, bir heves ya da moda akımı gibi algılanır. Hal böyle olunca 
durumun geçiciliği ve moda algısı, bütün propaganda birikimiyle Hıristiyan misyonerliğinin hanesine oldukça büyük bir artı olarak kaydedilir.

\section{Moğolların Postmodern Tezahürleri: Kent, Kitle İletişimi ve Kültürel Parçalanma}

Rasonyi (1993, 181), Moğol istilasının manevi değerleri saklayan kitleleri imha ettiğini, şehirleri ve medeniyet ocaklarını yaktığını söyler. Post modern zamanların Türkiye'sinde tarihin tekerrür ederek analojik manada ikinci Moğol istilasının yaşandığını söylemek, hatalı bir çıkarım olmayacaktır. İki farklı açıdan böyle bir analojik bağın kurulması mümkün ve uygundur.

İlk olarak Doğu'dan gelen Moğol istilasının fiziksel tahribatının çok daha şiddetli bir benzeri, bugün Batıdan gelen coca-colonizasyon dalgası ve kültür mühendisliği sayesinde baş döndürücü bir hızla hayata geçirilmektedir. İlkinde değerleri saklayan kitleler ve şehirler imha edilmesine rağmen değerler ayakta kalmayı başarmış ve şehirler yeniden inşa edilmiştir. Bugün kitleler fiziksel bir tecavüze maruz kalmamasına rağmen geriye dönüşü imkânsıza yakın bir şekilde değerler, kolektif kültür ve hafıza imha edilmekte, söz konusu değersizleşme şehirler büyüdükçe ironik biçimde katlanarak artış göstermektedir.

Analojinin ikinci gerekçesi daha içe dönük ve öz sorgulama maksatlıdır. Moğol istilasından dalgalar halinde Anadolu'ya kaçan Türk boyları, yerleşik hayata geçtikçe sosyal statï bakımından hızla çevreden merkeze taşınmışlar ve kendilerinden bir sonraki dalga ile gelen akrabalarını bile göçebe kültürlü olmalarından ötürü çevreden saymışlardır. Modern Türkiye, mega-kentleriyle bahse konu merkez-çevre geçişlerinin benzer ama çok daha yoğun bir biçiminin tezahürüne sahne olmaya devam etmektedir. Merkez, çevre, Halk İslam'1 ve Kitabi İslam kavramları, tıpkı hemen toplanıp gidiverecekmiş gibi üst üste ve mantar misali bir günden diğerine akıl almaz bir hızla çoğalan beton koruganları ile modern kentlerimizde olduğu gibi Türk toplumsal yapısında da sık aralıklarla yeniden tartışılarak tanımlanmayı gerektiren muğlak kavramlar haline gelmiştir.

Kırsal toplumda daha çok öte dünyaya ait olan din, kente geldiğinde ahiret hayatına vurgu yapmayı ikinci plana alarak bu dünyanın dini haline getirilir. Daha mantıklı, ahlaki ve toplumsal yaşantıyı önceleyen bir dini yapı ve dini söylem ise aslında dini alanın daralmasına, hemen tamamen dünyevi alanla örtüşmesine, profan değerlerle aynı mikyasta ölçülmeye başlamasına vesile olur. Anlaşılır ve örneklenebilir hale gelen her olgunun anlam içeriği hızla 
basitleşerek, özelliğinden bir şeyler kaybeder. Bu bağlamda vazgeçmek, özellikle köy ve kent arasında gidip gelmeye devam eden tranzisyonel toplum ve bu ara kültüre ait birey için çok daha kolay hale gelir. Kolayca vazgeçen birey, yenisini edinmek istediğinde, üstelik bu yeni avantajlarıyla birlikte altın tepside sunuluyor ve hem kutsal, hem dünyevi vaatler içeriyorsa geçiş sürecinde zorlanmayacaktır.

Köyden kente göç olgusu; merkeze yerleştiği hüsn-ü zannına kapılan bireyin tahayyül çıtasını yukarılara taşır ve taleplerini körüklerken, sanayileşemeden büyüyen kentlerin büyük köyler haline gelmesine, kır hayatı ve geleneksel mekanik bağların, semtlerde heterojen öbeklenmeler sayesinde canlılığını muhafaza etmesine, merkez ve çevre kavramlarının muğlaklaşmak suretiyle iç içe geçmesine sebep olmaktadır. Merkezi ve çevresi belli olmayan, mekanik ve organik aidiyetlerin eşzamanlı olarak varlıklarını sürdürdükleri bu yapı içerisinde, doğal olarak Yüksek İslam ve Halk İslam'ı ya da geleneksel İslam'ın da ayırt edici özellikleri bakımından yoksullaştıklarını söylemek mümkündür. Ancak büyük köyler halinde gelişen şehirler ve kenar-kuşak toplulukları olarak göçmenler vasitasıyla, şehrin kadim dokusuna da nüfuz etmek suretiyle dünyevi gerekçeleri efsunlayarak kendi yapılarına uyduran Halk İslam'ı yoğunluklu bireşimler ortaya çıkmıştır. Üstelik bu bireşimler Atacan (1990)'ın da belirttiği gibi günümüz toplumsal yapısında dini işlevlerden çok sosyal dayanışma gibi dünyevi işlevlere sahip rasyonel dayanışma grupları halini aldıklarından, bir ucundaki işsiz ve gündelikçilerden diğer ucundaki iktisadi ve kültürel seçkinlere varıncaya kadar toplumsal yelpazenin her yerinden müntesiplere sahiptir. Sözü edilen kentli neo-tekke Müslümanlığı, bütün fiilleri için makul ve ustalıklı dini meşrulaştırma biçimleri üretirken mevcut halleriyle sosyal yelpazenin her iki ucuna da çare olmaya devam eden yapılardan mürekkeptir. Bahse konu yapılar, en aşağıdakiler için kitle iletişimi sayesinde sürekli öykünmeleri sağlanan ayrıcalıklılar ile aynı halkaya dâhil olma, statü atlama, rüyalarına dokunma fırsatı verirken, üsttekilere de istedikleri zaman düşük hayatlara temas ederek hallerine şükretme, küçük iyiliklerle vicdanlarını rahatlatma, öte dünya için yatırım yapma şansı tanır.

Cemaat ve tarikatların, kültür emperyalizmi ve postmodern, kültürel tektipleştirici aktarımın en yoğun hissedildiği kent hayatında, bu duruma reddiyeler geliştirerek ortaya çıkan tepkisel teo-sosyolojik gruplaşmalar oldukları söylenebilir. Hal böyleyken bir yandan apriori olarak içerdikleri vecd, diğer yandan tepkisel eylem ve söylemleriyle sadece Ortodoks dini yapının değil aynı zamanda rasyonel kent dindarlığının da tepkisine neden olurlar. Genel- 
likle oldukça uzaklaştıkları halde din ve İslam adına sergiledikleri heterodoks tavır, hem Ortodoks dini grubun temsil edildiği çevrelerde, hem de seküler bir dünya görüşüne sahip kentli bireyde dinin ontolojik ve epistemolojik içeriğine karşı soru işaretleri oluşturur. Eninde sonunda tepkisel biçimde ortaya çıkmış olan söz konusu gruplar, hem siradan dindar bireyin hem de daha belirsiz olmasına rağmen belli dini kalıplara saygılı rasyonel grupların ana akımdan kopmalarına, yeni açmazlara, belirsizlik ve nihayetinde inançsızlıklara doğru istikamet değiştirmelerine vesile olur. Bir kere kırılma ve kopmalar başladığında birey-yoğun, kalabalık ve yüksek iletişim ağına sahip kent sokakları, yeni salgınlara son derece elverişli olduklarını gösterirler. Hatta zamanla sanal iletişim ağlarının sahte dünyası, bu kopuşu kitlesel bir mecraya ya da oldukça uzun süre etkisini koruma potansiyeline sahip bir moda algısına dönüştürebilir.

Bireysel dindarlık algıları, sosyal ve kültürel değişimlerle eşgüdüm içerisinde şekillenir. Göç sürecinde kırsal, geleneksel hayatın birincil, samimi ve dayanışmacı ilişkiler sistemi ile gündelik hayatın zamansal ritmi geride kalır. Kentte işleyen kurumsallaşmış, bürokratik, resmi, anonim ve ikincil ilişkiler düzeni, her şeyden önce zaman ve mekân kullanımındaki algıları, tasavvurları ve pratikleri değiştirir. Kent yaşantısında zaman kavramı kırsalda hiç olmadığı kadar önem kazanır. Hayat kentte daha hızlı akmakta, ilişkiler ise yasalar, mevzuatlar ve prosedürler üzerinden kurulmaktadır. Kent dindarl1$\breve{g} 1$ bu anlamda şehrin bireyselleşmiş ve sekülerleşmiş kültürü üzerinden yeni rasyonel yorumlarla şekillenir. Kentte dini otorite kurumsallaşırken, dini bilgi kaynakları ve bu kaynaklara ulaşım imkânları genişler. Kent bu bakımdan dinde eleştirel düşüncenin, sorgulama ve bireyselleşmenin ortaya çıkmasına fırsat hazırlar. Kent ailesi, geleneksel geniş ailenin eğitim, dayanışma gibi işlevlerini yok ederek bu görevleri başka toplumsal kurumlara devrettiği için çocukların dini sosyalleşmesindeki bilgi kaynakları ve ortamları değişmiştir. Modern kentin yapısal değişimi bağlamında dini sosyalleşmenin araçları ve mekânları da değişirken dini yapı; dindarlık, özellikle dini çoğulculuk ve dini bireycilik, yeni dini hareketler ve cemaatlerin tezahürü ile farklı etkileşimlere açıktır (Çelik, 2012, 300).

Büyük köy-kentleri ve etraflarında sosyo-ekonomik yapılara göre oluşturulmuş gettolarıyla milenyumun kentli bireyi, tamamen yapay da olsa kendisini ebeveynlerinden ve toplumun geri kalanından daha güçlü, özgür ve bilge hissetmektedir. Çünkü tüketildiğinden daha hızlı üretilen bilginin kaynağına sahiptir ve bu çok güvenilir kaynak, kendisini dünyanın merkezine koymasını 
sağlayan bu muktedir güç, her zaman elinin altında ve çok kolay ulaşılabilir konumdadır. Zihin dünyasında kutsala ayrılmış alanı giderek daraltan, bütün soru işaretlerine kendiliğinden yetkin cevaplar bulabilen, şüpheye düştüğü her bilgi kırıntısını kendince doğrulayabilen ya da yanlışlayabilen devasa bir güce sahiptir: Kitle iletişimi. Bu sihirli değnek sayesinde birey, her türlü bilgi kirliliği ve manipülasyona açık bir zihinle özgüven patlaması yaşamakta, dokunduğu her şeyi izah ve tasnif edebilme gücünün olduğuna inanmaktadır.

Hem kentin çokkültürlü doğası, hem de kitle iletişiminin devasa gücü, dini ötekiler konusunda daha yakın ve güncel bilgiler almaya olanak sağladığından, en azından yakın çevrede ve bireysel bakış açılarında öteki çizgilerinin geleneksel keskinliklerini yitirmesine vesile olur. Bu vakıanın genel tanımlamasını "hoşgörü" kelimesinden ziyade milenyum insanına ve kent yaşamına mahsus bir duyarsızlık ve umursamazlıkla açıklamak mümkündür. Böyle bir ortamda birkaç on yıldan yüzlerce yıla kadar değişmeyen temel vaatlerini paylaşmaya yanaşmayan dini yapıların, yayılımlarını kolaylaştırmak, müntesip kazanmak, en azından kaybetmemek için bu tavırlarında yumuşamaya gitmeleri söz konusudur. Üstelik küresel aktörler tarafından inşa edilmeye çalışılan tek dünya dini düşüncesi de söz konusu yumuşamanın önünü açar. Müntesipleri için öngördüğü vaatleri paylaşmaya başladığı andan itibaren bizatihi dinin kendisi ontolojik ve epistemolojik açmazlara hazır hale geldiği bir kısır döngünün ilk kıvılcımını ateşler.

İşte bu noktada küreselleşmenin sıradan bireyin dini hayatını ve dini kimliklerini nasıl etkilediği meselesi cevap arayan bir soru olarak karşımıza çıkmaktadır. Sosyal kimlik teorisi, temel kabulleriyle bu soruyu şöyle cevaplandirmaktadir:

a. Her birey kendisine prestij sağladığını ve gururlandırdığını düşündüğü pozitif bir sosyal kimliğe sahip olmak, zaten sahipse kimlik aidiyetini devam ettirmek ister.

b. Aidiyet duyulan sosyal grup ile öteki gruplar arasında yapılan sübjektif kıyaslamalar, bireyin sahip olmakla duygusal açıdan doyuma ulaştığı sosyal kimliğin temel dayanaklarını oluşturur.

c. Öteki gruplarla yapılan karşılaştırmaların sonucu, beklenenden daha nesnel ya da tüm öznelliğine rağmen sahip olunan kimlikle gurur duyulmasına yetmeyecek özelliklere sahip olduğu durumlarda, birey daha olumlu özelliklere sahip olduğu başka bir gruba aidiyet duyarak eski grubunu terk etmek ya da öteki gruplarla yaptığı karşılaştırmanın ölçütlerini değiştirerek grup kimliğine olumlu değerler yüklemek gibi 
iki seçenekten birisini tercih ederek sosyal kimlik ihtiyacını karşılayacaktır (Tajfel-Turner, 1986, 16).

Söz konusu dini kimlikler olunca da benzer durum geçerlidir. Birey kendi dini kimliği ile diğer dini gruplar arasında karşılaştırma yaptığında gruba aidiyetini ya da özsaygısını yitirecek sonuçlarla yüzleşmek durumunda kalırsa, öncelikle bir değişim arayışı içerisine girmesi mümkündür. Değişimin nasıl bir içerikle ve hangi istikamette gerçekleşeceği ise bireysel ve sosyal olmak üzere iki farklı stratejinin ortaya çıkmasına bağlıdır. Sosyal kimlik kuramına göre, böyle bir karar vermek zorunda kalan birey, müntesibi olduğu dini grup içinde kalmaya devam etmek ya da kötü sonuçlardan dolayı aidiyet duygusunu kaybettiği eski dini kimliğini başka bir dini grup aidiyeti ve kimliğiyle değiştirmek seçeneklerinden birisini tercih edecektir (Lorenzi-Cioldi - Doise, 1994, 75).

\section{Sonuç}

Din ve sağladığı kolektivite, bireye samimi bir aidiyetle sarılıp sahiplenebileceği yeterince saygın bir kimlik vermez ya da zaman içerisinde çeşitli sebeplerle kurumsallığını yitirerek sorgulamaya açık hale gelirse, birey de doğal olarak söz konusu kimliğe atfettiği değeri sorgulayacaktır. Bu durumda kurumsal dinin sağladığ 1 kolektif kimlik ve samimi aidiyet duygusunun hangi hallerde sorgulamaya açılma ihtimalinin daha fazla artacağı, çözülmesi gereken bir sorun olarak belirmektedir. Her ne kadar katkı yapılabilecek eksiklikleri bulunsa da sosyolojik bir bakış açısıyla, bize göre din;

a. Öteki algısını muğlaklaştırırsa,

b. İddiasını/müjdesini (kurtuluş), tıpkı yakın dönemde Vatikan'ın “Dinlerarası Diyalog" adını verdiği Hıristiyanlaştırma projesinde İslam dünyası için koçbaşı olarak kullandığı, daha sonra darbe teşebbüsünde bulunacak olan dini grubun Hıristiyan ve Yahudiler için sıkça tekrarladığı "Amentüde biriz" söyleminde olduğu gibi -belirgin bir öteki olarak tanımlanmış olsun ya da olmasın- diğer dinsel yapılarla paylaşırsa,

c. Kimlik çerçevesini belirleyen norm ve değerler bütününün canlılık ve zamana karşı akılla desteklenmiş bütünlüğünü koruyamazsa,

ç. Ticari ve siyasi alanlarla birlikte günlük yaşantıda zahiri varlığını (din dili kullanımının yoğunlaşması vb.) artırırken beşeri alan ve uygulamalarda (bireysel ve toplumsal ahlak, dayanışma gibi konulardaki emir ve yasakların uygulanması vb.) değer kaybı yaşamaya başlarsa, 
d. Zahiri görünüm biçimleri ve ritüellerinin (abdest, namaz, oruç, hac, dua, geleneksel dindarlık tezahürleri vb.) müntesiplerce tekrarlanma sıklığ1 ve bunlara duyulan sadakat, gözle görülür düşüşler gösterirse,

e. Söylemlerini zamanın ruhuna -zeitgeist- uygun bir dille güncellemeyi beceremezse,

f. Toplumsal değişimle çelişmediğini teolojik olarak ispatlayamazsa,

g. Fetihçi ve tebliğci özelliğini güncelleyemez, yitirir ve donuk bir ideolojiye dönüşürse,

h. Bireysel dindarlık algılarını kurumsal olarak inşa edemez ya da yönetemez duruma gelirse,

i. Ortodoks dini düşünceye itiraz ve protestolarla meydana gelen firkalaşmalar, kabul edilebilir seviyeden daha hızlı ve keskin biçimde hayat bulmaya, birbirlerine ve ortodoks söyleme daha yoğun zarar vermeye başlarsa,

j. Kendi fasit dairelerinde her söyledikleri makbul, adeta hatadan münezzeh dini karizmanın, farklı gerekçelerle (cehalet, siyaset, ticaret, ihanet vb.) sarf ettiği ve kitle iletişimi sayesinde hızla yayılan düşünce ve sözlerinin, kurumsal ortodoks dinin genel söylemlerine verdiği zararı önleyecek tedbirler alamazsa,

k. İfade edilen gelişmelerden herhangi biri ya da birkaçının birden gerçekleşme durumu söz konusu olursa, tehlike çanları çalmaya başlamış demektir. Bu durumda kurumsal dini söylemin üreticileri, belirlenmiş tedbir ya da tedbirler dizgesini müntesipler nezdinde, bireysel dindarlık algılarında hayata geçiremezlerse evrimsel bir döngünün son merhalesine girilmiş demektir. Benzer durumdaki bir dinin inananı, bitme ihtimali olmayan anlam arayışını tatmin etmek için kendisine yönelecek başka kıbleler, yüz sürecek başka mihraplar bulmakta gecikmeyecektir.

Müslüman toplumlarda, belirtilen gerekçelerle yakın geçmişte olduğundan daha gözle görülür hale gelmeye başlayan deizm/ateizm olguları, postmodern dünyanın mevcut kolektif aidiyetlerini eriterek yeni arayışlara soktuğu birey için kısa süreli bir boşluktan başka bir şey ifade etmeyecektir. Bununla birlikte anlam arayışı tatmin edilmeyen bireyin, kısa sürede yakın döneme ait patolojileriyle sırf dini gruplar ve propaganda konusunda tarihsel uzmanlığa sahip Hristiyan yayılmacılı̆̆ 1 için açık hedef haline getirileceği değerlendirilmektedir. Son tahlilde devam eden mücadelenin nihai galibi, yüksek bir ihtimalle 
sırf dini grupları da açık ara geride bırakacak şekilde kurumsal misyonerlik çalışmaları sayesinde her biri devasa organizasyonlara dönüşmüş olan mezhepleriyle Hiristiyanlık olacaktır.

\section{Kaynaklar/References}

Akgül, Mehmet. "Modernlik-Modernleşme, Postmodernlik Sekülerleşme ve Din”. Din Sosyolojisi El Kitabı. ed. Niyazi Akyüz, İhsan Çapcığ̆lu. 181-210. Ankara: Grafiker Yayınlar1, 2012.

Atacan, Fulya. Cerrahiler. İstanbul: Hil Yayınları, 1990.

Ayata, Ayşe. “Geleneksel ve Modern Dayanışma”. Dünya'da ve Türkiye’de Güncel Sosyolojik Gelişmeler. 325-339. Ankara: Sosyoloji Derneği Yayınları, 1994.

Berger, Peter L. Kutsal Şemsiye. çev. Ali Coşkun. İstanbul: Rağbet Yayınları, 2005.

Cevizci, Ahmet. Felsefe Sözlüğü. İstanbul: Paradigma Yayınları, 2010.

Çelik, Celaleddin. “Göç, Kentleşme ve Din”. Din Sosyolojisi El Kitabı. ed. Niyazi Akyüz, İhsan Çapcıŏ̆lu. 297-306. Ankara: Grafiker Yayınları, 2012.

Çelik, Celaleddin. Geleneksel Şehir Dindarlı̆̆ından Modern Kent Dindarlı̆̆ına. İstanbul: Hikmetevi Yayınları, 2013.

Günay, Ünver. Din Sosyolojisi. İstanbul: İnsan Yayınları, 2011.

Laborit, Henri. Insan ve Kent. çev. Bertan Onaran. İstanbul: Payel Yayınları, 1990.

Lorenzi-Cioldi, Fabio - Doise, Willem. "Identité Sociale et İdentité Personelle”. Stéreotypes Discrimination et Relations Intergroupes. ed. Richard Y. Bourhis, Jacques P. Leyens. 69-96. Liége: Mardaga, 1994.

Rásonyi, László. Tarihte Türklük. Ankara: Türk Kültürünü Araştırma Enstitüsü, 1993.

Sarıbay, Ali Y. "Kent: Modernleşme ile Postmodernleşme Arasında Köprü”. Kentte Birlikte Yaşamak Üstüne. ed. Ferzan Bayramoğlu Yıldırım. İstanbul: Dünya Yerel Yönetim ve Demokrasi Akademisi Yayınları, 1996.

Simmel, Georg. Bireysellik ve Kültür. çev. Tuncay Birkan. İstanbul: Metis Yayınları, 2009.

Tajfel, Henri - Turner, John C. "An İntegrative Theory of İntergroup Conflict”. The Social Psychology of lntergroup Relations. ed. William. G. Austin, Stephan Worchel. 7-24. California: Brooks-Cole, 1986.

Zijderveld, Anton C. Soyut Toplum. çev. Cevdet Cerit. İstanbul: Pınar Yayınları, 1985. 
